\title{
Pre Menarcheal Knowledge and Some Socio- Behavioral Variables: A Community Based Comparative Study on Bengali Women
}

\author{
Madhumita Debnath ${ }^{1}$,Jhuma Sarkar ${ }^{2}$,Baijayanti Baur ${ }^{3}$ Nirmalya Sinha ${ }^{4}$ \\ ${ }^{I}$ (Department Of Physiology, Dr. K.L.Bhattacharyya College, India.) \\ ${ }^{2,3,4}$ Department Of Community Medicine, Midnapore Medical College, Paschim Medinipur, India.)
}

\begin{abstract}
Menarche is often considered as a significant milestone in the life of a woman. However, in developing countries like India, menstruation is still recognized as a taboo which prevents adolescent girls from getting appropriate scientific knowledge related to physiology of menstruation and menstrual hygiene from her society or surroundings. Lack of formal education and poor socioeconomic condition leads to inappropriate practices of menstrual hygiene with adverse outcomes. A community based cross-sectional comparative study was undertaken among 160 rural and urban women aged 10-60 yrs with the help of a pre-designed, semi structured schedule to assess and compare the menarcheal knowledge and practices associated with menstrual hygiene. The mean age at menarche was found to be higher in rural women than their urban counterpart across all age groups. A definite trend of menarcheal age shifting was also observed. Significantly higher number (52\%) of urban women had knowledge about menstruation before menarche and exhibited much better awareness, which seems to be related to a better socio-economic condition and higher level of formal education. The use of sanitary napkins was significantly higher in urban women (72\%) whereas majority of rural women (61.8\%) still use old clothes as absorbent. Awareness about menstruation and menstrual hygiene can be improved if we acknowledge the issue from the core and act so that women in their menstruating years get proper health education and have better access to low-cost sanitary napkins.
\end{abstract}

Key words: Menarche, menstrual hygiene, premenarcheal knowledge, Reproductive health, sanitary napkin.

\section{Introduction}

Puberty is the stage in the growth and development of female characterized by a series of anatomical, physiological and behavioral changes. Typically occurring between 12-14 years of age, it is the period when girls experience their first menstrual bleeding. Menarche, the onset of menstrual bleeding, is often taken as an important sign of sexual maturity in women. ${ }^{[1,2]}$ The average age at menarche varies greatly between populations. It has been shown to vary from eight years to nineteen years across world. ${ }^{[3,4]}$ Indian studies have put the value from 12.1 yrs in Bengali girls to 15.4 yrs in girls coming from low socio economic background in Maharashtra. ${ }^{[5,6]}$ Most sources have argued that average age of menarche has dropped significantly from 1840s till date. ${ }^{[7]}$ Although purely a biological phenomenon, menstruation is often linked to many false beliefs, misconceptions and unhygienic practices. Pre menarcheal knowledge in adolescence is mostly shaped by socioeconomic, cultural and religious factors along with the level of formal education of a girl and her family. It strongly influences the practices associated with menstrual hygiene in women in their menstruating years. Pre menarcheal knowledge and practices associated with menstrual hygiene can be regarded as a significant component of reproductive health and fertility in women in general, as poor menstrual hygiene may not only potentiates infections in the reproductive tract or urinary-tract, sexually transmitted diseases like cervical cancer but also influence infant and child health and survival from prenatal infection. ${ }^{[8]}$

With this background the present study was designed to assess and compare the pre menarcheal knowledge, beliefs, practices associated with menstrual hygiene as well as menarcheal age of both urban and rural Bengali women aged 10-60 yrs.

\section{Materials And Method}

Study design: A community based cross-sectional comparative study was conducted among rural and urban Bengali women aged 10-60 yrs in West Bengal, India in 2015. Out of 20 districts in West Bengal, one (West Midnapore) was selected at random. In West Midnapore there are 29 rural blocks. One block was selected at random and the study was carried out in one of the sub-centre. Data were collected from the 5 villages under this sub-centre. For the urban sample, random sampling was applied to select one Municipal area (Bidhan Nagar) out of 128 municipalities in West Midnapur. Random sampling method was applied to select one ward out of 25 wards in Bidhan Nagar municipality. 
Sampling: Taking data from an Indian study in West Bengal, $72.1 \%$ of the urban participants had pre menarcheal knowledge, calculated sample size became 149 with allowable error $10 \%$ and $95 \%$ confidence limit. ${ }^{[5]}$ We took data from 160 Bengali women, 110 from rural and 50 from urban areas.

Tool and techniques: A pre-designed, pre-tested, semi-structured schedule was prepared in local language (Bengali) to collect information regarding background characteristics of a participant, age at menarche, pre menarcheal knowledge and practices followed to maintain menstrual hygiene. The study was carried out on a 'house to house' basis in both urban and rural areas ensuring one to one interaction with every participant. Informed consents were taken from all participants after explaining them the purpose of the study. Confidentiality of the participants was ensured and no follow-up visit was planned.

Ethical issues: The entire study protocol and schedule was duly approved by Institutional Ethical Committee of Medical College, Kolkata.

Data entry and analysis: Responses from all participants were complied in Microsoft Excel worksheet and analyzed accordingly. Non-parametric $X^{2}$ tests were performed to find out the degree of association between variables of different groups. $P$ value less than $<.05$ was considered as significant.

\section{Results}

Among the studied 160 Bengali women,110 were from rural and 50 were from urban areas. More women in rural areas were in the age group 10-20 yrs. $(44.5 \%$ ) followed by $38.2 \%$ in $21-30$ yrs. age group, whereas in urban areas it was $28 \%$ for 31-40 yrs. age group and 26\% for 51-60 yrs. In rural areas 51\% followed the Islam religion, while in urban areas majority $(96 \%)$ were Hindus. $72.7 \%$ of rural participants belonged to lower socioeconomic status (class IV and class V of Prasad' scale), whereas $94 \%$ urban participants belonged to higher socioeconomic status (class I of Prasad's scale). Mean age at menarche were recorded in different decades of reproductive age groups in both urban and rural areas(Table 2) which showed that there was age shifting towards lower direction (line diagramme) which was more in urban women. Mean age at menarche was $12.06 \mathrm{yrs}$ in urban girls belonging to 10-20 yrs, where as rural girls of the same age group experienced menarche a little later (12.76 yrs). Similar differences in the age at menarche were evident in all other age groups, i.e. 20$30,30-40,40-50$, and 50-60 yrs.

Table 3 showed that $52.0 \%$ of the urban Bengali women had some knowledge of menstruation before menarche compared to only $12.7 \%$ of rural women $(p-.000)$. Peer group in urban areas was the main source of information $(61.5 \%)$, where as family members other than mother were the main informants for rural girls $(50 \%)$.Significant differences in the different areas of premenarcheal knowledge like cause of menstruation ( $p$ .002 ), source of menstrual blood ( $p-.000)$ were found between rural and urban women. When talking about their first reaction towards menarche, 58\% of urban participants reported that they felt scared during menarche. $38 \%$ of urban compared to $10 \%$ of rural women said that they felt discomfort, but never scared. $21.8 \%$ of the rural participants said that they remain indifferent during menarche. When asked whether or not they knew that a woman can become pregnant after menarche, $80 \%$ of urban women responded in affirmative compared to $34.5 \%$ rural respondents $(p<.000)$. Table 4 showed that nearly similar proportion of women (Rural-75.5\% vs urban-74\%) faced some kind of imposed restrictions during menstruation, specially in religious activity(Rural$91.6 \%$,Urban-100\% ), followed by cooking \& serving food in rural area(15.6\%) and playing (18.9\%)in urban area. Majority of the rural women $(82.7 \%)$ compared to urban(42.0\%) still considered menstruation as taboo that prohibits female from talking about it openly. It was good to see that none of the urban participants were restricted to attend schools during menstrual period. The number was very low for rural participants (3.6\%)also. Significant differences in response between rural and urban participants were also evident when questions were asked about practices of menstrual hygiene $(p-.000), 72 \%$ of urban women use sanitary napkins compared to $22.7 \%$ of the rural women. Most of the rural women (61.8\%) prefer to use old cloth as absorbent. Both rural and urban women take bath and keep themselves clean during menstrual bleeding $(100 \%)$.Regarding the site of disposal of absorbent after their use varied between urban and rural areas, $84 \%$ of urban participants dispose absorbent in public dustbin where as $68.18 \%$ of the rural women bury their absorbents in ground after use. $6.36 \%$ of the rural women said that they keep their used absorbent in bathroom(Table 5). Table 6 showed that sanitary napkins use during menstruation significantly varied according to literacy status, socio-economic strata and religion.

\section{Discussion}

Menarche is regarded as a vital milestone that profoundly changes a woman's life. Premenarcheal knowledge in women and their menstrual practices are strongly influenced by socio-cultural background, educational status of the individual and religious beliefs. In many instances women, especially the adolescent girls, remain ignorant about actual scientific facts related to menstruation and menstrual hygiene. This may not only result in adverse reproductive health in a woman but may also potentiate the possibilities of prenatal infections. The present study was designed to explore the comparative aspects of pre-menarcheal knowledge and 
practices of menstrual hygiene among rural and urban Bengali women aged 10-60 yrs with special emphasis on menarcheal age in different decades of reproductive life. The present study has shown that mean menarcheal age in rural and urban Bengali girls belonging to age group 10-20 were 12.76 and 12.06 yrs respectively. A study by Dasgupta and Sarkar reported the menarcheal age of rural adolescent Bengali girls to be 12.8 yrs which is in agreement with the present study. ${ }^{[9]}$ Another comparative study by Datta \& others in 2012 has shown that mean menarcheal age in rural and urban adolescent school girls in Howrah District of West Bengal were 12.2 and 12.1 yrs respectively. ${ }^{[5]}$ Differences in the age at menarche between rural and urban population were clearly visible in other age groups (20-30, 30-40, 40-50 and 50-60 yrs) also, might be due to the difference of influence of socioeconomic, environmental and behavioral factors in rural and urban area. Women from lower socio-economic stratum tend to have higher pre-menarcheal age in comparison to those coming from higher strata. This is in accordance to a study by Wronka et al in Poland in 2005. ${ }^{[10]}$ In this current study, a clear evidence of menarcheal age shifting had been observed. Menarcheal age in both rural and urban Bengali women seems to be advancing in a more or less steady way in lower direction. Similar lowering of the age at menarche was reported by Bagga and Kulkarni in a study conducted on Maharashtrian girl in India. ${ }^{[11]}$

Findings of our study showed that majority of rural girls were not informed about menarche before and experienced it without any preparation. The awareness level was much higher in Lebanese adolescent girls where $95.4 \%$ of the participants said that they had previous information on menstruation. ${ }^{[12]}$ In a study done in Amritsar city, India in 2012, 61.3\% of adolescent girls had awareness about menstruation prior to initiation of menarche. ${ }^{[13]}$ A similar study in Karnataka, India had shown that $33.27 \%$ of the urban and $35.82 \%$ and rural school girls had awareness before menarche. ${ }^{[14]}$ Similar studies with rural girls in Bengal have put the awareness level at $67.5 \% .{ }^{[9]}$ Much lower value of awareness in the present study may be due to a bigger range of age groups (10-60 yrs) among the participants and also the presence of taboo as found in Table 4 . In the present study, peer group came out to be the main informant $(61.54 \%)$ in urban areas followed by mother (34.6\%). Whereas in rural areas, the main source of premenarcheal knowledge was other family members $(50 \%)$. This is quite close to the values reported in a study on Bengali girls in 2012. ${ }^{[5]}$ Similar study in Nagpur, India reported that mother followed by sisters, friends and teachers were the main source of information. ${ }^{[15]}$ In a study conducted in Mansoura, Egypt, mass media was the main source of information about menstrual hygiene. ${ }^{[16]} \mathrm{We}$ found that nearly one fourth rural women $(22.7 \%$ ) had no idea that menstruation is a natural physiological process which was different from other studies done in Rajasthan and West Bengal. ${ }^{[17,18]}$ It is very sad to observe that the knowledge regarding the source of blood during menstruation was very poor among the rural respondents, whereas urban participants correctly identified uterus to be the source of blood which was quite similar to other studies. ${ }^{[15,18]}$ Participants showed variety of emotional responses during menarche like 'scared', extreme discomfort etc. A Similar study have reported anxiety, embarrassment even sense of guilt among respondents during menarche. ${ }^{[14]}$ When asked, $80 \%$ of the urban women in our study correctly said that a woman cannot conceive before menarche. On the contrary majority of rural respondents $(65.5 \%)$ said that they have no idea about the relationship between menarche and pregnancy. It is observable from our study that majority of the participants $(62 \%)$ in urban area feel comfortable to discuss and share information related to physical changes in puberty with their peer group, while rural participant prefer their mothers for discussion and support.

We found that majority of our studied females (both urban and rural areas) faced different kinds of imposed restrictions during menstruation, specially in religious activity, cooking and serving food, playing which was in well accordance with a study in Punjab where similar kind of restriction for visiting religious places and touching sacred books were observed in $72 \%$ of the respondents who practiced restrictions. ${ }^{[13]}$ Inadequate scientific knowledge regarding the physiology of menstruation and presence of taboos in the studied area specially rural area might be the reasons of imposed restrictions. While dealing with hygienic practices during menstruation we found that significantly more urban respondents were using sanitary napkins as compared to their rural counterpart. Similar observations can be obtained from other related studies on practices associated with menstrual hygiene. ${ }^{[9,13,15]}$ The disposal of used absorbent also varied between urban and rural participants. Reason as expressed by the rural women that they could not use sanitary napkins because of its unavailability in the local market and exorbitant price fully knowing that it would have been more hygienic. Other possible reasons might be some socio-economic factors like literacy status, financial condition or religion had a role in hygienic practices of the studied women, because we found that menstrual hygiene practices were more among literate women, belonging to higher socio-economic strata and Hinduism.

\section{Conclusion}

Investigators of the present study strongly felt that general awareness about menstruation was considerably poor among participants and the practices of menstrual hygiene were far from satisfactory among respondents particularly in rural areas. Both community based health awareness programme to remove taboos related to menstruation and school based programme on reproductive health specially on areas like physical 
changes in time of puberty, normal physiology of menstruation and healthy practices associated with it should be regularly carried out in these areas. Regular counseling through Adolescent Clinics are the other area of intervention to reduce age-old beliefs and superstitions. Sanitary napkins should also be made universally available at low cost to improve the level of menstrual hygiene. Researchers also suggest further study in this field in a wider scale.

\section{References}

[1]. Textbook of Medical Physiology. Guyton and Hall. Elsevier. Saunders.2008.

[2]. Basic and Clinical Endocrinology. Greenspan \& Baxter. Prentice Hall International. 4th ed.1994.

[3]. Herman- Giddens ME, Slora EJ, Wasserman RC, Bourdony CJ, Bhapkar MV, Koch GG, Hasemeier CM(1997). Secondary sexual characteristics and menses in young girls seen in office practice. A study from the pediatric research in office setting networks. Pediatrics.99. 505-512.

[4]. Graham MJ, Larsen U, and Xu X (1999) Secular trend in age at menarche in China: a case study of two rural counties in Anhui Province. Journal of Biosocial Science 31:251-261.

[5]. Adrija Datta, Nirmalya Manna, Mousumi Datta, Jhuma Sarkar, Baijayanti Baur, Saraswati Datta. Menstruation and menstrual hygiene among adolescent girls of West Bengal, India: A school based comparative study. GJMEDPH, Vol 1(5) SeptemberOctober 2012;50-57.

[6]. Rao S, Joshi S, Kanade A. Height Velocity, body fat and Menarcheal age of Indian Girls. Indian Pediatrics.1998;35: 619-28.

[7]. Tanner JM (1973) Trend toward earlier menarche in London, Oslo, Copenhagen, the Netherlands, and Hungary. Nature 245.'95-96.

[8]. Singh MM, Devi R, Garg S, Mehra M. Effectiveness of syndromic approach in management of reproductive tract infections in women. Indian J Med Sci 2001 Apr;55(4):209-14

[9]. Dasgupta A, sarkar M. Menstrual Hygiene: How hygienic is the adolescent girl? Indian J community Med 2008 Apr;33(2)77-80.

[10]. Wronka I, Pawlinska-Chmara R. Menarcheal age and socio-economic factors in Poland. Ann Hum Biol 2005,32:630-638.

[11]. Bagga A, Kulkarni S. Age at menarche and secular trend in Maharashtrian (Indian) girls. Acta Biol Szeged 44(1-4):53-57(2000).

[12]. Santina T, Wehbe N, Ziade FM, Nehme M. Assessment of beliefs and practices relating to menstrual hyiegine of adolescent girls in Lebanon. International Journal of health sciences and research 2013 Dec,3(12)75-88.

[13]. Kamaljit K, Arora B, Singh G K, Neki NS. Social beliefs and practices associated with menstrual hygiene among adolescent girls in Amritsar, Punjub, India. JIMSA April-June 2012, 25(2)69-71.

[14]. Kamath S, Ghosh D, Lena A, Chandrasekaran V. A study on knowledge and practices regarding menstrual hygiene among rural and urban adolescent girls in Udupi Taluk Manipal, India. Global journal and medicine and public health.2013;2(4);1-9.

[15]. Thakre SB, Thakre SS, Reddy M, Rathi N, Pathak K, Ughade S. Menstrual hygiene: knowledge and practices among adolescent school girls in Saoner, Nagpur district. Journal of Clinical and Diagnostic Research 2011 Oct, Vol-5(5):1027-1033.

[16]. El-Gilany AH, Badawi K. Menstrual hygiene among adolescent schoolgirls in Mansoura, Egypt. Reprod Health Matters 2005; $13: 147-52$

[17]. Khanna A, Goyal RS, Bhawsar R. Menstrual practices and reproductive problems: a study of adolescent girls in Rajasthan. J Health Manag 2005;7:91-107.

[18]. Yasmin S,Manna N,Mallik S,Ahmed A,Paria B Menstrual hygiene among adolescent school students : An in depth cross-sectional study in Urban community of West Bengal, India. IOSR-JDMS 2013 Mar-apr, Vol-5(6):22-26.

\section{Results}

Table 1: Demographic details of the study subjects $(n=160)$

\begin{tabular}{|c|c|c|c|}
\hline Variables & & Rural (n=110) & Urban $(n=50)$ \\
\hline \multirow{3}{*}{ Religion } & & No. $(\%)$ & No.(\%) \\
\hline & Hindu & $54(49.0)$ & $48(96.0)$ \\
\hline & Muslim & $56(51.0)$ & $02(04.0)$ \\
\hline \multirow{5}{*}{$\begin{array}{ll}\text { Age } & \text { groups(in } \\
\text { years) } & \end{array}$} & $(10-20)$ & $49(44.5)$ & $08(16.0)$ \\
\hline & $(21-30)$ & $42(38.2)$ & $05(10.0)$ \\
\hline & $(31-40)$ & $13(11.8)$ & $14(28.0)$ \\
\hline & $(41-50)$ & $02(1.82)$ & $10(20.0)$ \\
\hline & $(51-60)$ & $04(3.64)$ & $13(26.0)$ \\
\hline \multirow{5}{*}{$\begin{array}{l}\text { Socio-economic } \\
\text { status }\end{array}$} & Class I & $05(4.5)$ & $47(94.0)$ \\
\hline & Class II & $09(8.2)$ & $00(00.0)$ \\
\hline & Class III & $16(14.5)$ & $03(06.0)$ \\
\hline & Class IV & $40(36.4)$ & $00(00.0)$ \\
\hline & Class V & $40(36.4)$ & $00(00.0)$ \\
\hline \multirow{6}{*}{$\begin{array}{l}\text { Participant's } \\
\text { Education }\end{array}$} & Illiterate & $14(12.7)$ & $00(00.0)$ \\
\hline & Primary School & $30(27.3)$ & $02(04.0)$ \\
\hline & Middle School & $55(50.0)$ & $03(06.0)$ \\
\hline & $\begin{array}{l}\text { Higher } \\
\text { Secondary }\end{array}$ & $06(5.4)$ & $06(12.0)$ \\
\hline & Graduate & $05(4.6)$ & $18(36.0)$ \\
\hline & Post-Graduate & $00(0.0)$ & $21(42.0)$ \\
\hline \multirow[t]{6}{*}{ Father's Education } & Illiterate & $52(47.2)$ & $00(00.0)$ \\
\hline & Primary School & $20(18.2)$ & $03(06.0)$ \\
\hline & Middle School & $24(21.8)$ & $02(04.0)$ \\
\hline & $\begin{array}{l}\text { Higher } \\
\text { Secondary }\end{array}$ & $06(5.5)$ & $02(04.0)$ \\
\hline & Graduate & $08(7.3)$ & $28(56.0)$ \\
\hline & Post-Graduate & $00(0.0)$ & $15(30.0)$ \\
\hline Mother's Education & Illiterate & $66(60.0)$ & $02(04.0)$ \\
\hline
\end{tabular}


Pre Menarcheal Knowledge And Some Socio- Behavioral Variables: A Community ...

\begin{tabular}{|l|l|l|l|}
\hline \multirow{y}{*}{} & Primary School & $26(23.6)$ & $04(08.0)$ \\
\cline { 2 - 4 } & Middle School & $13(11.8)$ & $04(08.0)$ \\
\cline { 2 - 4 } & $\begin{array}{l}\text { Higher } \\
\text { Secondary }\end{array}$ & $01(0.91)$ & $12(24.0)$ \\
\cline { 2 - 4 } & Graduate & $01(0.91)$ & $22(44.0)$ \\
\cline { 2 - 4 } & Post-Graduate & $03(2.72)$ & $06(12.0)$ \\
\hline
\end{tabular}

Table-2: Mean Age at menarchae among rural and urban respondents $(\mathrm{n}=160)$

\begin{tabular}{|l|l|l|}
\hline \multirow{2}{*}{ Age group(in years) } & \multicolumn{2}{|c|}{ Mean age at menarche (years) } \\
\cline { 2 - 3 } & $\begin{array}{l}\text { Urban women }(\mathrm{n}=50) \\
\text { Mean }( \pm \mathrm{sd})\end{array}$ & $\begin{array}{l}\text { Rural women }(\mathrm{n}=110) \\
\text { Mean }( \pm \mathrm{sd})\end{array}$ \\
\hline $10-20$ & $11.36( \pm 0.92)$ & $12.76( \pm 0.89)$ \\
$21-30$ & $11.55( \pm 1.85)$ & $12.79( \pm 1.58)$ \\
$31-40$ & $12.64( \pm 0.82)$ & $13.34( \pm 1.02)$ \\
$41-50$ & $12.50( \pm 1.37)$ & $13.70( \pm 0.01)$ \\
$51-60$ & $12.97( \pm 1.05)$ & $13.76( \pm 1.33)$ \\
\hline
\end{tabular}

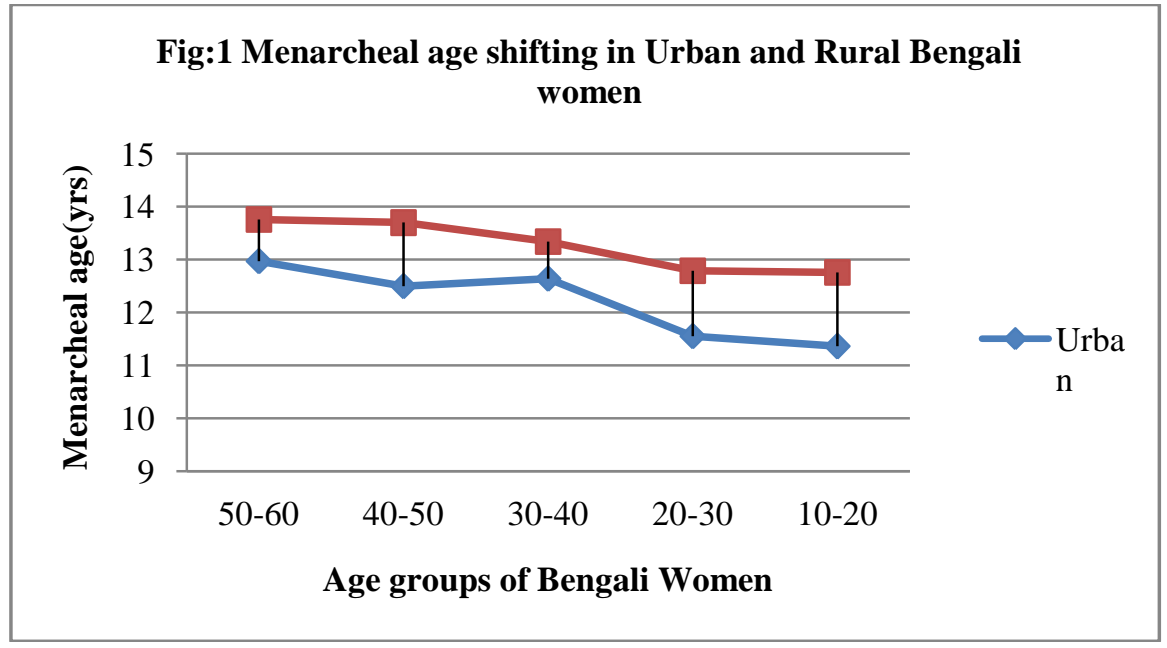

Table 3: Pre-menarcheal knowledge and awareness about menstruation among respondents $(n=160)$

\begin{tabular}{|c|c|c|c|c|}
\hline \multirow{2}{*}{\multicolumn{2}{|c|}{ Variables }} & \multicolumn{2}{|c|}{$\begin{array}{ll}\text { Rural } & \text { Urban } \\
(\mathrm{n}=110) & (\mathrm{n}=50)\end{array}$} & \multirow[t]{2}{*}{$\begin{array}{lll}\mathrm{X}^{2} & \mathrm{df} & \mathrm{p} \\
\text { value } & & \\
\end{array}$} \\
\hline & & No. $(\%)$ & No. $(\%)$ & \\
\hline $\begin{array}{l}\text { Premenarcheal knowledge } \\
\text { about menstruation }\end{array}$ & $\begin{array}{l}\text { Yes } \\
\text { No }\end{array}$ & $\begin{array}{l}14(12.7) \\
96(87.3)\end{array}$ & $\begin{array}{l}26(52.0) \\
24(48.0)\end{array}$ & $\begin{array}{ll}28.27 & 1 \\
.000^{* *} & \end{array}$ \\
\hline \multirow{3}{*}{$\begin{array}{l}\text { Source of information before } \\
\text { menarche*(positive response) }\end{array}$} & Mother & $03(21.4)$ & $09(34.6)$ & \\
\hline & Other family members & $07(50.0)$ & $04(15.4)$ & \\
\hline & Peer & $06(42.8)$ & $16(61.5)$ & \\
\hline \multirow[t]{2}{*}{$\begin{array}{l}\text { Knowledge about exact cause } \\
\text { of menstruation }\end{array}$} & Natural & $85(77.2)$ & $49(98.0)$ & $\begin{array}{l}9.381 \\
.002 * *\end{array}$ \\
\hline & Don't know & $25(22.8)$ & $01(02.0)$ & (yate's correction) \\
\hline \multirow{3}{*}{$\begin{array}{l}\text { Knowledge about exact } \\
\text { source of blood during } \\
\text { menstruation }\end{array}$} & Uterus & $03(02.7)$ & $35(70.0)$ & $\begin{array}{ll}93.11 & 2 \\
.000 * * & \\
\end{array}$ \\
\hline & Abdomen & $05(04.5)$ & $05(10.0)$ & \\
\hline & Don't know & $102(92.7)$ & $10(20.0)$ & \\
\hline \multirow[t]{3}{*}{$\begin{array}{l}\text { First reaction towards } \\
\text { menarche }\end{array}$} & Scared & $75(68.2)$ & $29(58.0)$ & $\begin{array}{ll}21.64 & 2 \\
.000 * * & \end{array}$ \\
\hline & $\begin{array}{l}\text { Felt discomfort but not } \\
\text { scared }\end{array}$ & $11(10.0)$ & $19(38.0)$ & \\
\hline & Indifferent & $24(21.8)$ & $02(04.0)$ & \\
\hline $\begin{array}{l}\text { Awareness that a woman can } \\
\text { become pregnant after } \\
\text { menarche }\end{array}$ & $\begin{array}{l}\text { Yes } \\
\text { No }\end{array}$ & $\begin{array}{l}38(34.5) \\
72(65.4)\end{array}$ & $\begin{array}{l}40(80.0) \\
10(20.0)\end{array}$ & $\begin{array}{l}28.43 \\
.000 * *\end{array}$ \\
\hline $\begin{array}{l}\text { Comfortable to share } \\
\text { information about puberty } \\
\text { related physical changes } \\
\text { with* }\end{array}$ & $\begin{array}{l}\text { Parents } \\
\text { Siblings } \\
\text { Peer } \\
\text { Others } \\
\text { Did not discuss }\end{array}$ & $\begin{array}{l}72(65.4) \\
27(15.5) \\
15(13.6) \\
23(20.9) \\
01(0.01)\end{array}$ & $\begin{array}{l}24(48.0) \\
10(20.0) \\
31(62.0) \\
04(15.4) \\
03(06.0)\end{array}$ & \\
\hline
\end{tabular}

Multiple responses $\left(\mathrm{X}^{2}\right.$ not done $) \quad$ significant 
Pre Menarcheal Knowledge And Some Socio- Behavioral Variables: A Community ...

Table 4: Restrictions practiced during menstruation $(n=160)$

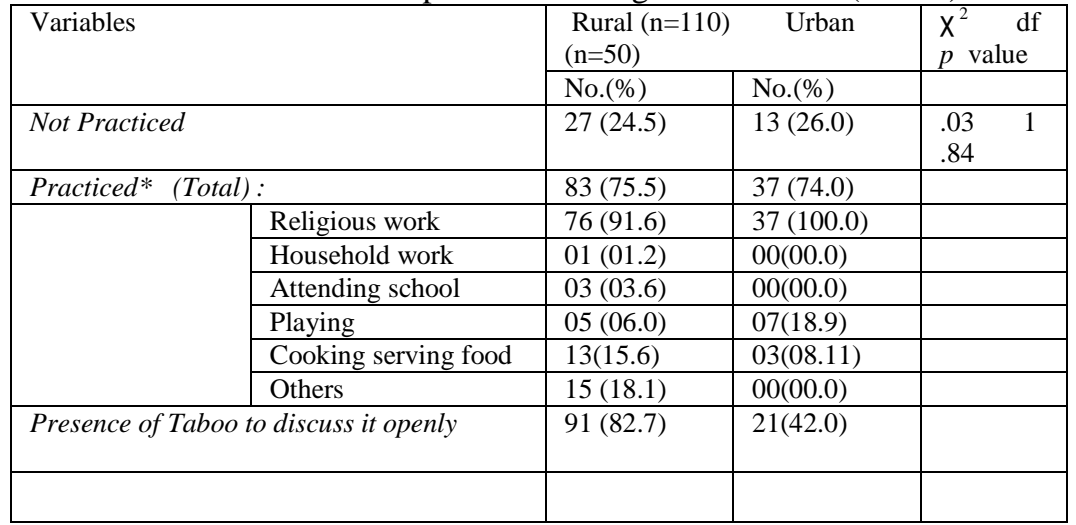

*Multiple responses

Table-5: Menstrual hygiene practices among rural and urban respondents $(n=160)$

\begin{tabular}{|c|c|c|c|c|}
\hline \multirow{2}{*}{\multicolumn{2}{|c|}{ Variables }} & \multicolumn{2}{|c|}{$\begin{array}{l}\text { Rural }(n=110) \quad \text { Urban } \\
(\mathrm{n}=50)\end{array}$} & \multirow[t]{2}{*}{$\begin{array}{l}X^{2} \text { df } p \\
\text { value }\end{array}$} \\
\hline & & No. (\%) & No. (\%) & \\
\hline \multirow[t]{4}{*}{ Type of absorbent } & Sanitary napkin & $25(22.7)$ & $36(72.0)$ & $\begin{array}{ll}35.38 & 1 \\
.000 & \end{array}$ \\
\hline & Old cloth & $68(61.8)$ & $10(20.0)$ & $\begin{array}{l}\text { (sanitary vs } \\
\text { other) }\end{array}$ \\
\hline & New cloth & $10(09.1)$ & $00(0.0)$ & \\
\hline & Mixed & $07(06.4)$ & $04(08.0)$ & \\
\hline \multicolumn{2}{|c|}{$\begin{array}{l}\text { Taking bath regularly during } \\
\text { menstruation }\end{array}$} & $110(100)$ & $50(100)$ & \\
\hline \multirow{5}{*}{$\begin{array}{l}\text { Disposal of used } \\
\text { absorbent }\end{array}$} & Public dustbin & 09 (08.2) & $42(84.0)$ & \\
\hline & Bathroom & $07(06.4)$ & $00(00.0)$ & \\
\hline & Bury in ground & $75(68.2)$ & $01(02.0)$ & \\
\hline & Domestic refuge & $02(01.8)$ & $07(14.0)$ & \\
\hline & Others & $17(15.5)$ & $00(00.0)$ & \\
\hline
\end{tabular}

Table 6: Distribution of participants according to menstrual hygiene practice and selected socio economic variables. $(n=160)$

\begin{tabular}{|c|c|c|c|}
\hline Variables & $\begin{array}{l}\text { Sanitary } \\
\text { napkins as } \\
\text { absorbent }\end{array}$ & $\begin{array}{l}\text { Any other } \\
\text { materials used } \\
\text { as absorbent }\end{array}$ & $\mathrm{X}^{2} \quad$ df $\quad p$ value \\
\hline $\begin{array}{l}\text { Literacy status } \\
\text { Illiterate }(n=14) \\
\text { Literate }(n=146)\end{array}$ & $\begin{array}{l}01(07.2) \\
59(40.4)\end{array}$ & $\begin{array}{l}13(92.8) \\
87(59.6)\end{array}$ & $\begin{array}{lcc}4.69 & 1 & .03 \\
\text { (yate's correction) }\end{array}$ \\
\hline $\begin{array}{l}\text { Socio economic } \\
\text { status } \\
\text { Class I }(\mathrm{n}=52) \\
\text { Class II }(\mathrm{n}=09) \\
\text { Class III }(\mathrm{n}=19) \\
\text { Class IV }(\mathrm{n}=40) \\
\text { Class V }(\mathrm{n}=40)\end{array}$ & $\begin{array}{l}37(71.2) \\
04(44.4) \\
08(42.1) \\
07(17.5) \\
05(12.5)\end{array}$ & $\begin{array}{l}15(28.8) \\
05(55.6) \\
11(57.9) \\
33(82.5) \\
35(87.5)\end{array}$ & $.000 * *$ \\
\hline $\begin{array}{l}\text { Religion } \\
\text { Hindu(n=102) } \\
\text { Muslim(n=58) }\end{array}$ & $\begin{array}{l}52(51.0) \\
08(13.8)\end{array}$ & $\begin{array}{l}50(49.0) \\
50(86.2)\end{array}$ & $.000^{* * *}$ \\
\hline
\end{tabular}

